Replying to questions regarding uranium deposits, Mr. Sandys said that the most promising region in Great Britain for uranium discoveries is in Cornwall. Pockets of uranium ore occur there; but the quantities so far found would not justify the expense of mining and treatment. The Government's decision to rely on uranium deposits overseas is therefore not a question of policy, but of necessity.

\section{Expenditure of the Department of Scientific and Industrial Research}

IN a written answer to a question regarding the expenditure of the Department of Scientific and Industrial Research, on November 12, Mr. J. A. Boyd-Carpenter, Financial Secretary to the Treasury, agreed that there had been some slight fall in real expenditure of the Department in 1952-53 compared with 1951-52 and 1950-51. The 1953-54 estimates for the Department, however, provided for an increase of about $£ 400,000$ over the 1952-53 level, and a general understanding had been reached between the Department and the Treasury which provided for the gradual expansion of the Department's activities over the next five years.

\section{Analytical Abstracts}

THE Society of Public Analysts and Other Analytical Chemists has provided abstracts of the literature on analytical chemistry for readers of The Analyst ever since the journal was first published in 1876. For the past four years these abstracts have been prepared by the Bureau of Abstracts and supplied to members of the Society and to subscribers to The Analyst under the title British Abstracts $C$. The Bureau will cease to exist at the end of this year, and British Abstracts will no longer appear in its present form. The Society has therefore decided to issue a new publication, to be called Analytical Abstracts, which will cover the whole range of analytical literature in the same way as did British Abstracts C. Analytical Abstracts will be edited by Dr. Norman Evers and published for the Society by W. Heffer and Sons, Ltd., of Cambridge. It will be published each month in a format similar to that of the abstracts included in The Analyst prior to 1950 and will be available in the new year to members of the Society and to subscribers on the usual terms; it will also be sold separately at $50 s$. a year, including the index, or at $60 s$. a year, printed on one side only, without the index.

\section{Journal of Protozoology}

THE Society of Protozoologists is to publish a new Journal of Protozoology, beginning in the spring of 1954. Papers concerned with original work on any aspect of the study of Protozoa may now be submitted to the editor, William Trager, Rockefeller Institute for Medical Research, 66th St. and York Ave., Now York 21, N.Y. The journal will consist of four issues a year. The annual subscription will be 9 dollars for all except graduate students, for whom it will be 6 dollars. Inquiries regarding subscriptions and membership of the Society of Protozoologists should be addressed to Norman D. Levine, Secretary, College of Veterinary Medicine, University of Illinois, Urbana, Illinois.

\section{Ammonia Assimilation by Chlorella}

P. J. SyreTt (Ann. Bot., N.S., 17, 65, 1; 1953), in a study of the assimilation of ammonia by nitrogen- starved cells of Chlorella vulgaris, has observed that the addition of ammonium sulphate to the culture solution is followed immediately by the rapid assimilation of ammonia and a notable increase in the respiration-rate. This continues until all the ammonia has been assimilated or until some carbon reserve within the cells has been used up. The ammonia is converted into soluble organic nitrogenous compounds, free or combined $\alpha$-amino-nitrogen or amide-nitrogen during the initial phase of the experiment. Later a smaller proportion of the assimilated ammonia is found in these fractions while appreciable quantities of basic amino-acids are formed. With this assimilation there is an increase in the rate of oxygen absorption and carbon dioxide liberation, the value of the respiratory quotient decreasing. Non-reducing sugar and acid-hydrolysable polysaccharide are rapidly metabolized. Possible explanations of these several phenomena are discussed in some detail. An explanation along the lines that the addition of ammonia to nitrogenstarved cells, which leads to the synthesis of amide, may result in the increased utilization of a substance such as adenosine triphosphate, and hence in an increased respiration-rate, is favoured.

\section{East African Agriculture and Forestry Research Organization : Report for 1952}

THE report for 1952 of the East African Agriculture and Forestry Research Organization is the first to be issued by the Organization from its new headquarters at Muguga, Kenya. In spite of the unrest in Kenya, considerable progress has been made and three new sections-namely, forest entomology, soil microbiology and soil physics-were opened. The first of these is undertaking a general survey of forest insects and investigating methods for preventing damage from the Cerambycid beetle, which causes serious losses in the exotic plantations of Kenya. Questions of nitrogen supply form the initial programme of the soil microbiology section, while the work of the soil physics department will be based chiefly on soil moisture problems as they affect both agriculture and forestry. In this connexion the recent survey carried out by Dr. C. R. Hursh, of the Southeastern Forest Experiment Station, United States Forest Service, on forest management in East Africa in relation to local climate, water and soil resources, is of special interest. In his report he instances cases where excessive felling of high forest has reduced the mist regarded as desirable by tea growers, and of land deterioration through faulty management of water supplies or overgrazing, and stresses the need for technological development of the results of scientific research if the remaining natural resources of the country are to be safeguarded. The sectional reports show that a healthy co-ordination is in operation both between the various departments within the East African Agriculture and Forestry Research Organization itself, and also with other neighbouring research organizations.

\section{Quartz Clocks of the Greenwich Time Service}

A GENERAL account of the development of the quartz clocks of the Greenwich Time Service, from the time of the installation of the first quartz clock in 1939 up to the present time, is given in a paper by H. M. Smith (Mon. Not. Roy. Astro. Soc., 113, 1 ; 1953). It is nearly ten years since the quartz clock completely displaced the pendulum clock in the 